\title{
WILLINGNESS-TO-PAY FOR RECREATION SERVICES OF URBAN GREEN ECOSYSTEM AND ITS VALUE ASSESSMENT IN REGIONAL SPECIFICITY: THE CASE OF A CITY IN CENTRAL CHINA, HUBEI PROVINCE
} CE WEN $^{1}$, YU ZHOU ${ }^{2}$, ZHI-WEI GUO ${ }^{3}$, LI-YA ZHAO ${ }^{4 *}$

${ }^{1}$ Institute of Urban Environment, Chinese Academy of Sciences, Xiamen 361021, China

${ }^{2,3,4}$ School of Resource and Environment, Hubei University, Wuhan 430062, China

Received: Sep 15, 2020; Accepted: Oct 05, 2020; Published: Nov 20, 2020; Paper Id.: IJEEFUSOCT20202

\section{INTRODUCTION}

Urban green ecosystem refers to the green infrastructure that provides service for people in and around the city, including forests, rivers, lakes and parks.Andnon-physical ecological services provided by urban green ecosystems cover urban climate regulation, biodiversity protection, air purification, noise reduction, pests control, etc. In addition, it can provide leisure and entertainment services for urban residents. It is a good place for people to enjoy daily entertainment, do outdoor exercise, get close to nature, and stimulate creative inspiration and aesthetic experience ${ }^{[1-4]}$. 
With the increase of urban built-up land and the development of urbanization, the area of urban green ecosystem tends to shrink, which forms a spatial dislocation with the increase of urban population and the demand for leisure and entertainment. "2018 China Green Land Bulletin" indicated that the greening rate of urban built-up areas in the country was $37.9 \%$, far lower than the $50 \%$ required by international standards. This directly affected the function of urban green ecosystem services in China and, to an extent, it had aggravated the problems of urban ash and heat island effect, and at the same time, it cannot meet the needs of urban people to pursue high quality life. ${ }^{[5]}$ Therefore, considering the background of urbanization and ecological civilization in China, it is crucially important to know how to improve the construction of urban green infrastructure as well as give full play to the service function of urban green ecosystem reasonably and comprehensively, so as to maximize its benefits, which is not only an urgent need to generate sustainable development of the cities, but also an effective way to satisfy people's pursuit of a better life.

As one of the important functions of urban green ecosystem, important value of leisure and entertainment services' can be directly detected by the evaluationof its economic value ${ }^{[6]}$. There are many evaluation methods for leisure and entertainment services. Among them, the ContingentValuation Method (CVM) proposed by Davis in 1963, which had developed rapidly and had been considered to be the most widely used for qualities public goods value evaluation method in foreign ecological and environmental economics in the past 10 years ${ }^{[7-8]}$. Itdirectly investigated people's willingness to pay (WTP) for an improvement of environmental qualities or resource protection measures under the hypothetical market situation, and estimated the economic value of environmental resources by people's WTP. Early studies mainly used socio-economic factors to explain the respondents' WTP. However, non-economic factors were also important to respondents' WTP and the amount of payment ${ }^{[9]}$.Therefore, more and more scholars introduced non-economic factors like preference and distance into the equation of WTP, and studied them along with socio-economic factors ${ }^{[10-12]}$.

Accordingly, this paper tookthe Central Districts of Wuhan City as case study, using Spearman correlation coefficient, Logistic, Ordinal models and actual survey data to analyse the residents' WTP and its affecting factors, and as well as the economic value of the entertainment service was calculated by the CVM, it aims to correctly understand and assess the value of entertainment in the urban green ecosystem of the Central Districts, and provide scientific basis for the local government to promote the construction of ecological civilization and improve the well-being of the residents.

\section{REGIONAL OVERVIEW AND RESEARCH METHODS}

\subsection{Regional Overview}

Wuhan $\left(113^{\circ} 41^{\prime}-115^{\circ} 05^{\prime} \mathrm{E}, 2^{\circ} 58^{\prime}-31^{\circ} 22^{\prime} \mathrm{N}\right) \quad$ is located in the middle of China, it covers an area of $8569.15 \mathrm{~km}^{2}$, with a population of 10.7662 million. Yangtze river, the world's third longest river, and its largest tributary meet in Wuhan, known as "the City of River." Falling into the subtropical monsoon climate belt, Wuhan has annual average temperature of $17.3^{\circ} \mathrm{C}$, and annual average rainfall of over $1500 \mathrm{~mm}$,where animals and plants are abundant as natural resources. Plants in the city are mainly evergreen broad-leaved forest. The central city has a total of seven administrative regions, among which Hongshan District has the largest population and green area, while Qingshan district has the smallest population and Jianghan District has the least green area. 


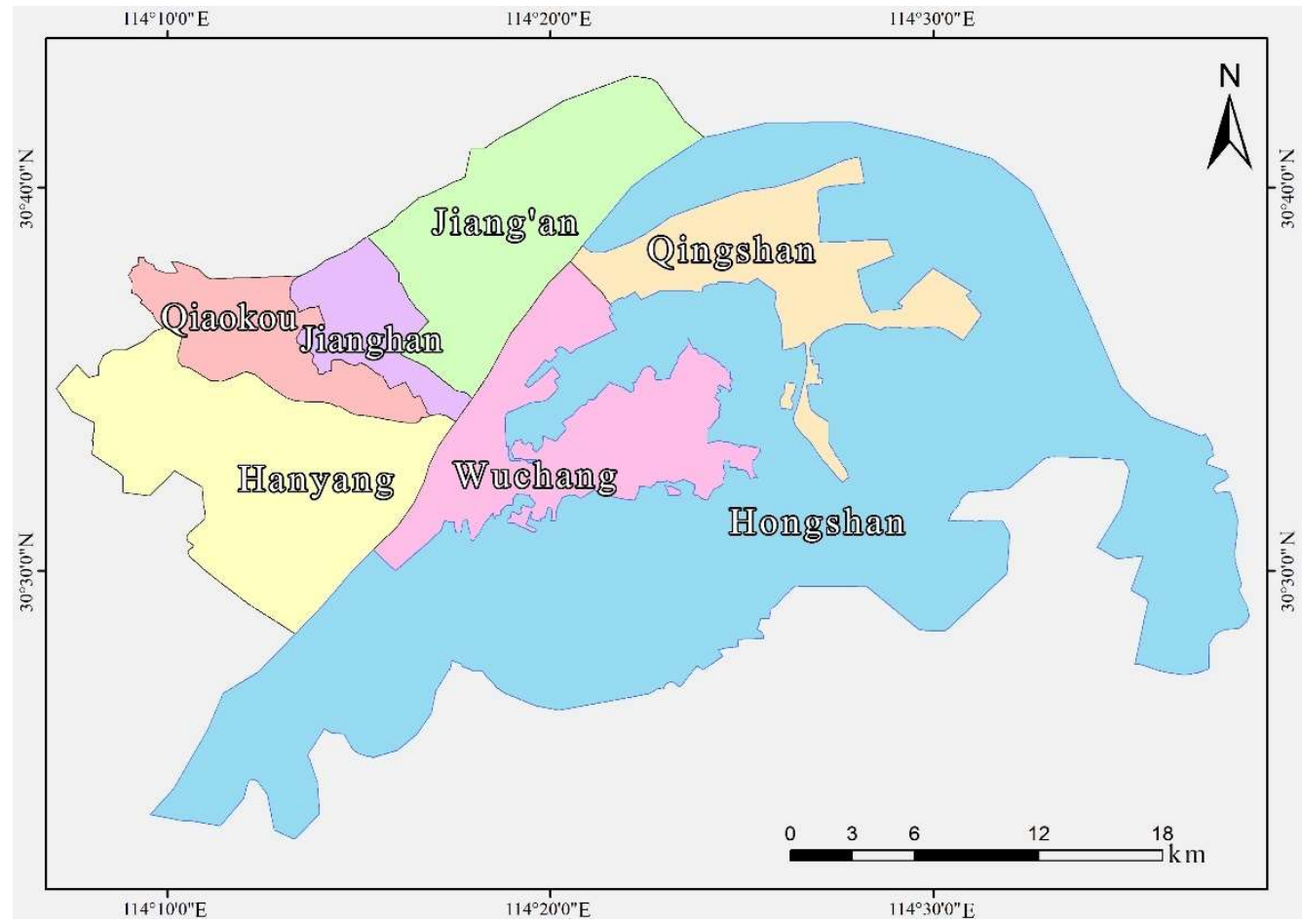

Figure 2.1 Administrative Division Map of Central District of Wuhan City

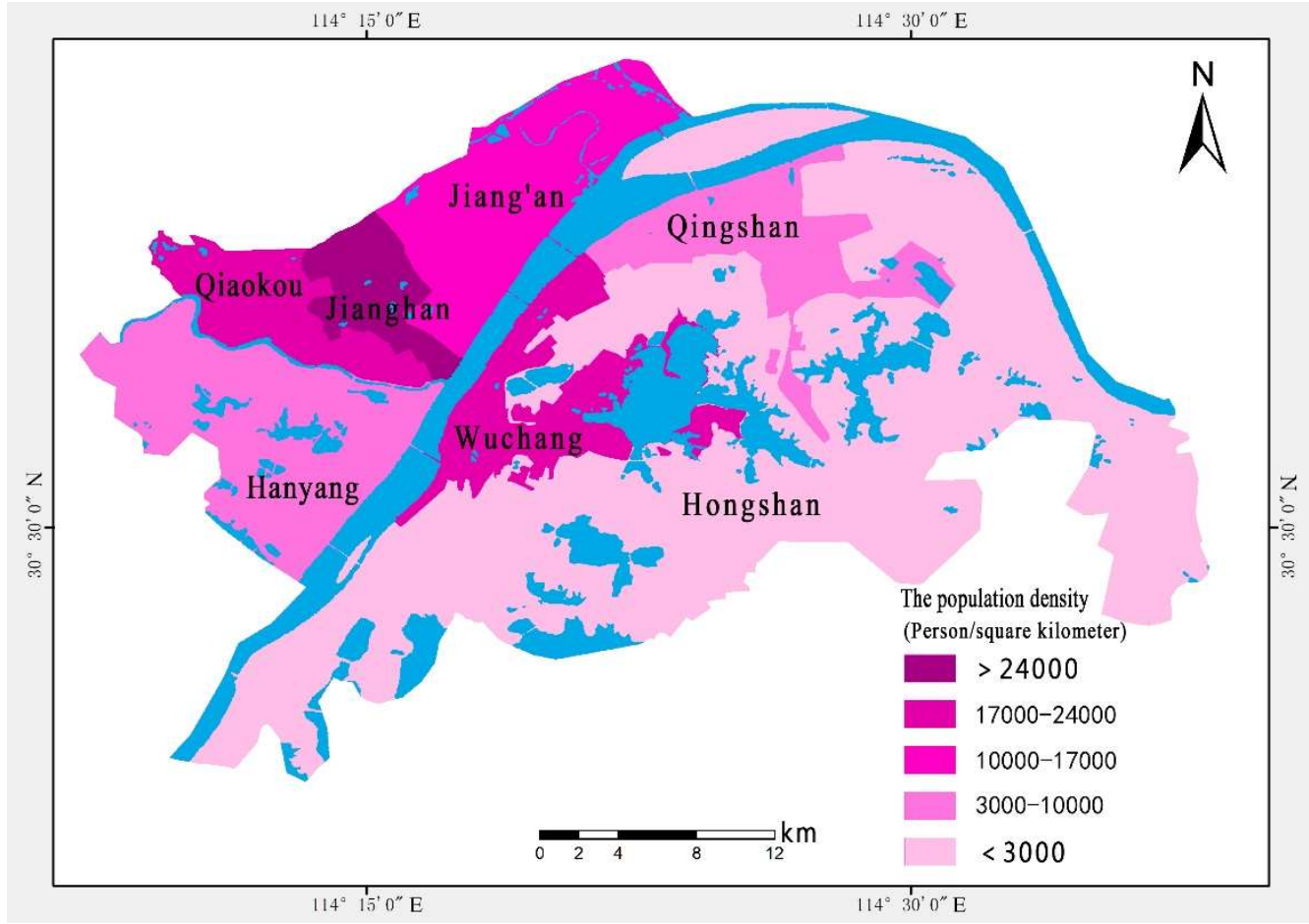

Figure 2.2 The Population Density Figure of Centre Districts in Wuhan

There are 166 lakes in Wuhan, 38 of which are located in the central city, such as East Lake, Yanxi Lake and Sand Lakes. The city has 76 parks, several plazas and green areas, and there are 35 central cities, such as East Lake Eco-tourism Scenic Spot and Ma'an Mountain Forest Park, Hankou River Beach, etc. The number of green ecosystems in the region is numerous and widespread (Figure 2.3, Tables 2.1). 


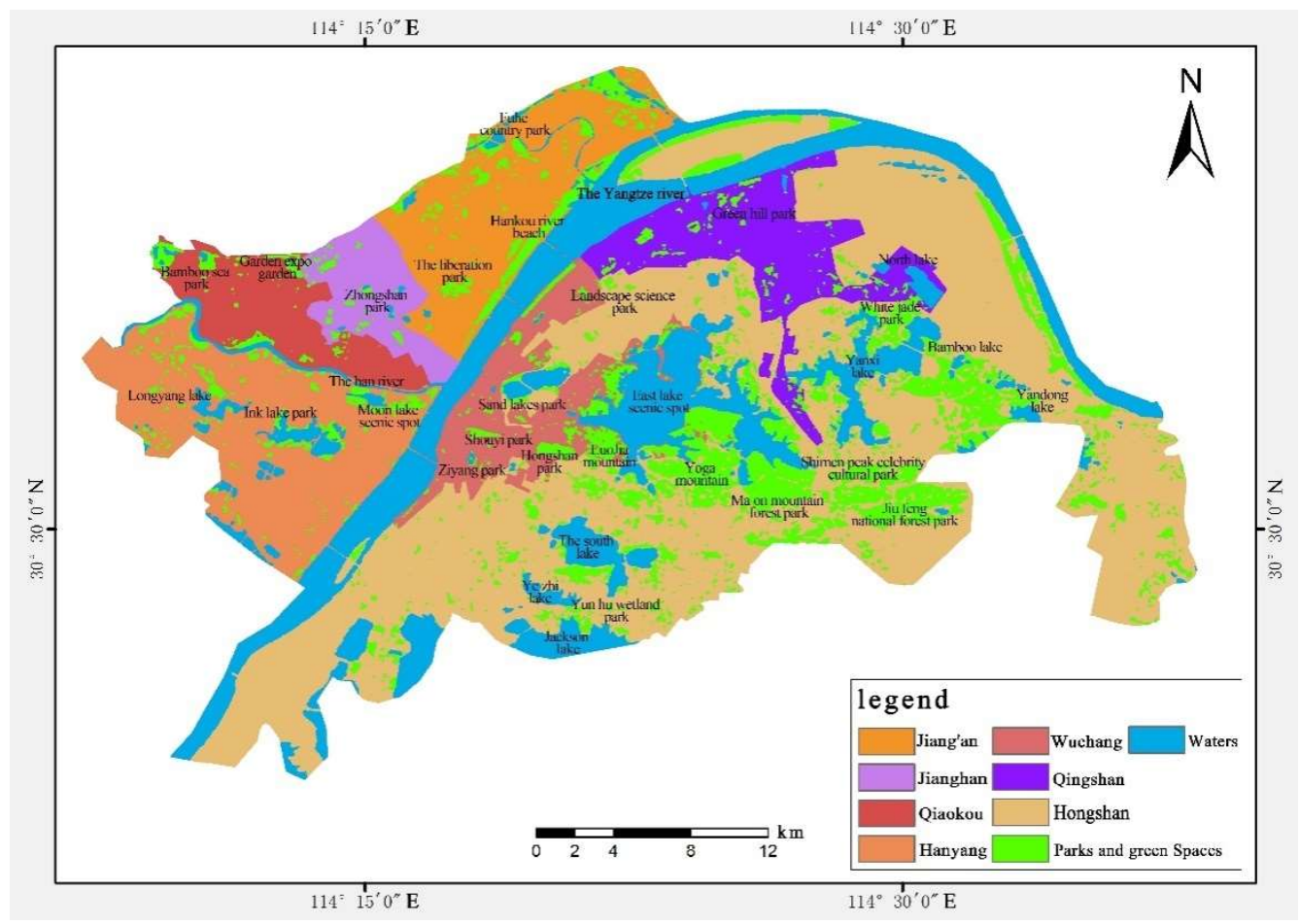

Figure 2.3 Green ecological system map of Centre Districts in Wuhan

Table 2.1 Statistical Table of Greenland Indicators in Downtown Area of Wuhan

\begin{tabular}{|l|c|c|c|c|c|}
\hline \multicolumn{1}{|c|}{ District } & $\begin{array}{c}\text { Land area } \\
\left(\mathbf{k m}^{2}\right)\end{array}$ & $\begin{array}{c}\text { Permanent } \\
\text { Population } \\
(\text { thousand })\end{array}$ & $\begin{array}{c}\text { Built-up Green } \\
\text { Area Rate }(\%)\end{array}$ & $\begin{array}{c}\text { Built-up Green } \\
\text { Area } \\
(\text { Hectare })\end{array}$ & $\begin{array}{c}\text { Park Green Area } \\
\text { per Person } \\
\left(\mathbf{m}^{2} \text { per person }\right)\end{array}$ \\
\hline Wuchang & 64.58 & 1274.00 & 34.51 & 2042.14 & 8.73 \\
\hline Qiaokou & 40.06 & 867.10 & 35.00 & 1466.74 & 12.52 \\
\hline Qingshan & 57.12 & 526.80 & 36.24 & 1547.86 & 10.30 \\
\hline Jiang'an & 80.28 & 961.30 & 39.34 & 1892.89 & 10.60 \\
\hline Hongshan & 573.28 & 1609.90 & 40.06 & 3287.60 & 3.60 \\
\hline Jianghan & 28.29 & 729.50 & 21.72 & 614.45 & 11.70 \\
\hline Hanyang & 111.54 & 648.50 & 36.89 & 1748.66 & \\
\hline
\end{tabular}

Data source: Wuhan Yearbook, 2017

\subsection{Survey Design}

This research adopted implementable and acceptable questionnaires. The contents of the questionnaires mainly included four aspects. The first part is the introduction, which mainly defines the urban green ecology system and outlines the general situation of the urban green ecological system resources and its entertainment function. The second part covers the social economic information of the respondents such as gender, age, place of residence. The third part containsthe residents' subjective opinions displaying their understanding and satisfaction degree of the leisure entertainment services of the urban green ecological system, as well as their willingness to re-visit the service locations. The fourth part is the core part of the questionnaire with which the respondents were asked whether they are willing to pay for the construction of urban green 
ecological system development or not. If their answers were affirmative, they would be expected to give their affordably highest pay.

The core questions addressed by the questionnaire are as follows:

(1) If you visit the urban green ecosystem such as greenway, parks, scenic spots, despite time and place, and whether (or not) you would like to pay a fee (e.g., for infrastructure)?

(1) Yes, (2)No.

If not, please give us your reason.

(2) If you are willing to pay the fee, what's your acceptable highest pay amount each year?

According to the preliminary investigation results, while referring to be previous studies, this questionnaire set up 29 payment options, as shown in table 2.2 .

Table 2.2 Questionnaire Payment Card

\begin{tabular}{|l|l|l|l|l|}
\hline (1) 1 yuan & (2) 2 yuan & (3) 3 yuan & (4) 4 yuan & (5) 5 yuan \\
\hline (6) 6 yuan & (7) 7 yuan & (8) 8 yuan & (9) 9 yuan & (10) 10 yuan \\
\hline (11) 20 yuan & (12) 30 yuan & (13) 40 yuan & (14) 50 yuan & (15) 60 yuan \\
\hline (16) 70 yuan & (17) 80 yuan & (18) 90 yuan & (19) 100 yuan & (20) 200 yuan \\
\hline (21) 300 yuan & (22) 400 yuan & (23) 500 yuan & (24) 600 yuan & (25) 700 yuan \\
\hline (26) 800 yuan & (27) 900 yuan & (28) 1000 yuan & \multicolumn{2}{|l|}{ (29) above 1000 yuan } \\
\hline
\end{tabular}

Data resource: Processed from survey

CVM method has deviations due to feint, payment, strategy and resistance from the respondents. These deviations may affect the accuracy of the results. Therefore, when designing the questionnaire, the investigators were unified, trained, enabled to explain the importance of urban green ecological system to respondents to reduce the deviation. Questionnaires were designed to be concise and succinct, guaranteeing that each respondent can finish it within 3 minutes.

\subsection{Data Sources}

Typical CVM sample size is $100 \sim 3000^{[13]}$. Considering such factors as recovery rate, this study adopted face-to-face interviews as the investigation main method, distributing 2230 copies of questionnaires in seven district areas. Sorting out invalid questionnaire with gaps, contradiction and other problems and excluding them, we received 2168 valid questionnaires, which accounted for $97.2 \%$.

Table 2.3 Distribution of Survey Samples

\begin{tabular}{|l|l|l|l|}
\hline \multicolumn{1}{|c|}{ District } & \multicolumn{1}{c|}{ Total Released } & \multicolumn{1}{c|}{ Effective Sample } & \multicolumn{1}{c|}{ Effective Rate/\% } \\
\hline Wuchang & 1010 & 1001 & 99.1 \\
\hline Qiaokou & 130 & 126 & 96.9 \\
\hline Qingshan & 120 & 115 & 95.8 \\
\hline Jiang'an & 140 & 134 & 95.7 \\
\hline Hongshan & 600 & 571 & 95.2 \\
\hline Jianghan & 120 & 113 & 94.2 \\
\hline Hanyang & 110 & 108 & 98.2 \\
\hline Central Districts & 2230 & 2168 & 97.2 \\
\hline & & & \\
\hline
\end{tabular}


Data resource: Processed from survey

\subsection{Theoretical Framework and Research Methods}

Through IBM SPSS 22 software, we described the characteristics of the respondent information and the relationship between WTP and payment amount with the Spearman correlation coefficient, which was a nonparametric estimator, using two variables of rank size as the linear correlation analysis. The calculation method is shown in formula (1).

$$
r_{s}=1-\frac{6 \sum_{i}\left(x_{i-} y_{i}\right)^{2}}{n\left(n^{2}-1\right)}
$$

In the formula, $r_{s}$ means the Spearman correlation coefficient between the respondents feature information and their WTP or pay amount. $x_{i}$ represents the feature information of the respondents, including socioeconomic status and subjective perception factors; $y_{i}$ represents WTP or pay amount. $\mathrm{n}$ isthe number of observations.

To enhance the analysis accuracy, we further established binary Logistic model between the influencing factors and WTP, to analyse the key factors influencing the respondents' WTP. Respondents' WTP were typical binary variables. 0 represents refusal to pay, 1 represents willingness to pay. The basic expressions of binary Logistic model are as follows:

$$
p(y=1)=\frac{\exp \left(\beta_{0}+\beta_{1} x_{1}+\cdots+\beta_{n} x_{n}\right)}{1+\exp \left(\beta_{0}+\beta_{1} x_{1}+\cdots+\beta_{n} x_{n}\right)}
$$

In the formula, $p(y=1)$ is the probability of respondents willing to pay. $\beta_{0}$ means the intercept of regression equation. $x_{1}, x_{2}, \ldots, x_{\mathrm{n}}$ represent the various explanatory variables, namely the feature information of the respondents. $\beta_{1}, \beta_{2}, \ldots, \beta_{\mathrm{n}}$ are regression coefficient. And $\exp \left(\beta_{\mathrm{i}}\right)$ is the probability of being willing to pay.

Meanwhile, we analysed the key factors affecting respondents pay amount though the Ordinal model. Suppose that there were $k+1$ levels of pay amount, then $\mathrm{k}$ formulas were corresponded:

$$
L_{i}=\operatorname{In}\left[\sum_{j=1}^{i} P(Y=j \mid X) / \sum_{j=i+1}^{k+1} P(Y=j \mid X)\right]=\alpha_{i}+\beta_{i} X
$$

In the formula, $L_{i}$ is the $i$ th ordered the Ordinal model. $i$ means the level of response variable payment amount level. $Y$ represents response variables. $X$ represents the independent variable vector. $\alpha_{i}$ stands for the $i$ th intercept parameter of the model. $\beta_{i}$ means slope vector. $P(Y=j \mid X)$ means the probability of respondents' payment amount in a certain level.

According to He Ke's ${ }^{[14]}$ former research, we set the arithmetic average of payment amount as uppermost limit of the average WTP, while calculating the lowest limit by Spike formula, represented by formula (4). Considering the city green ecosystem services, the local in the centre district, the total value of recreation service is shown in formula (5).

$$
\begin{aligned}
& \left\{\begin{array}{l}
E(\text { WTP }) \text { Maximum }=\sum_{i=1}^{n} A_{i} P_{i} \quad i=1,2,3, \cdots, n \\
E(\text { WTP }) \text { Minimum }=E(\text { WTP }) \text { Maximum } \times \text { Percentage of WTP }
\end{array}\right. \\
& \left\{\begin{array}{l}
Q[\text { Maximum }]=E(W T P)[\text { Maximum }] \cdot \alpha \\
Q[\text { Minimum }]=E(W T P)[\text { Maximum }] \cdot \alpha
\end{array}\right.
\end{aligned}
$$

In the formula, $E(W T P)$ stands for the respondents' average annual amount of arithmetic mean value. $A_{i}$ is the payment amount. $P_{i}$ is the probability that a sample with willingness to pay choosing the certain amount. $n$ stands for number of samples with willingness to pay. $Q$ is the value of urban green ecosystem leisure service. $\alpha$ is number of permanent residents in Wuhan. 


\section{RESULTS AND ANALYSIS}

\subsection{Descriptive Statistics of the Questionnaire}

Table 3.1 shows that the distribution of the samples was ideally normal, confirming the basic principle of sampling statistics and showing certain representativeness. Among the respondents, male accounted for 50.1\% while female accounted for $49.9 \%$, confirming that the sex ratio was realistic. Respondents were mainly composed of youth and middle-aged, predominantly under the age of 50 with a proportion of $93.9 \%$. They generally graduated from college or above, who were relatively highly educated. Yet, their average monthly income was 6000 yuan or less. There were 851 students among the respondents. Their income level was low. Residents may also be inclined to declare lower income level in the questionnaire to protect personal privacy.

Table 3.1 Statistical Description of Social Attribute Variables of Respondents

\begin{tabular}{|c|c|c|c|c|}
\hline Variable & Category & Frequency & Rate $/ \%$ & $\begin{array}{c}\text { Cumulative } \\
\text { Rate/\% }\end{array}$ \\
\hline \multirow[t]{2}{*}{ Gender } & Male & 1089 & 50.2 & 50.2 \\
\hline & Female & 1079 & 49.8 & 100.0 \\
\hline \multirow[t]{6}{*}{ Age } & 20 years old and below & 513 & 23.7 & 23.7 \\
\hline & 21-30 years old & 1020 & 47.0 & 70.7 \\
\hline & $31-40$ years old & 306 & 14.1 & 84.8 \\
\hline & $41-50$ years old & 193 & 8.9 & 93.7 \\
\hline & $51-60$ years old & 85 & 3.9 & 97.8 \\
\hline & 60 years old and above & 51 & 2.4 & 100.0 \\
\hline \multirow{5}{*}{$\begin{array}{l}\text { Educational } \\
\text { level }\end{array}$} & Primary and below & 22 & 1.0 & 1.0 \\
\hline & Junior Middle school & 92 & 4.3 & 5.3 \\
\hline & $\begin{array}{l}\text { Senior Middle school or } \\
\text { Technical secondary school }\end{array}$ & 319 & 14.7 & 20.0 \\
\hline & College & 1396 & 64.4 & 84.4 \\
\hline & Postgraduate and above & 339 & 15.6 & 100.0 \\
\hline \multirow{6}{*}{$\begin{array}{l}\text { Average } \\
\text { monthly } \\
\text { income }\end{array}$} & 2000 yuan and below & 866 & 39.9 & 39.9 \\
\hline & $2001-4000$ yuan & 496 & 22.9 & 62.8 \\
\hline & 4001-6000 yuan & 384 & 17.7 & 80.5 \\
\hline & $6001-8000$ yuan & 189 & 8.7 & 89.3 \\
\hline & 8001-10000 yuan & 117 & 5.4 & 94.6 \\
\hline & 10000 yuan and above & 116 & 5.4 & 100.0 \\
\hline
\end{tabular}

Data resource: Processed from survey 


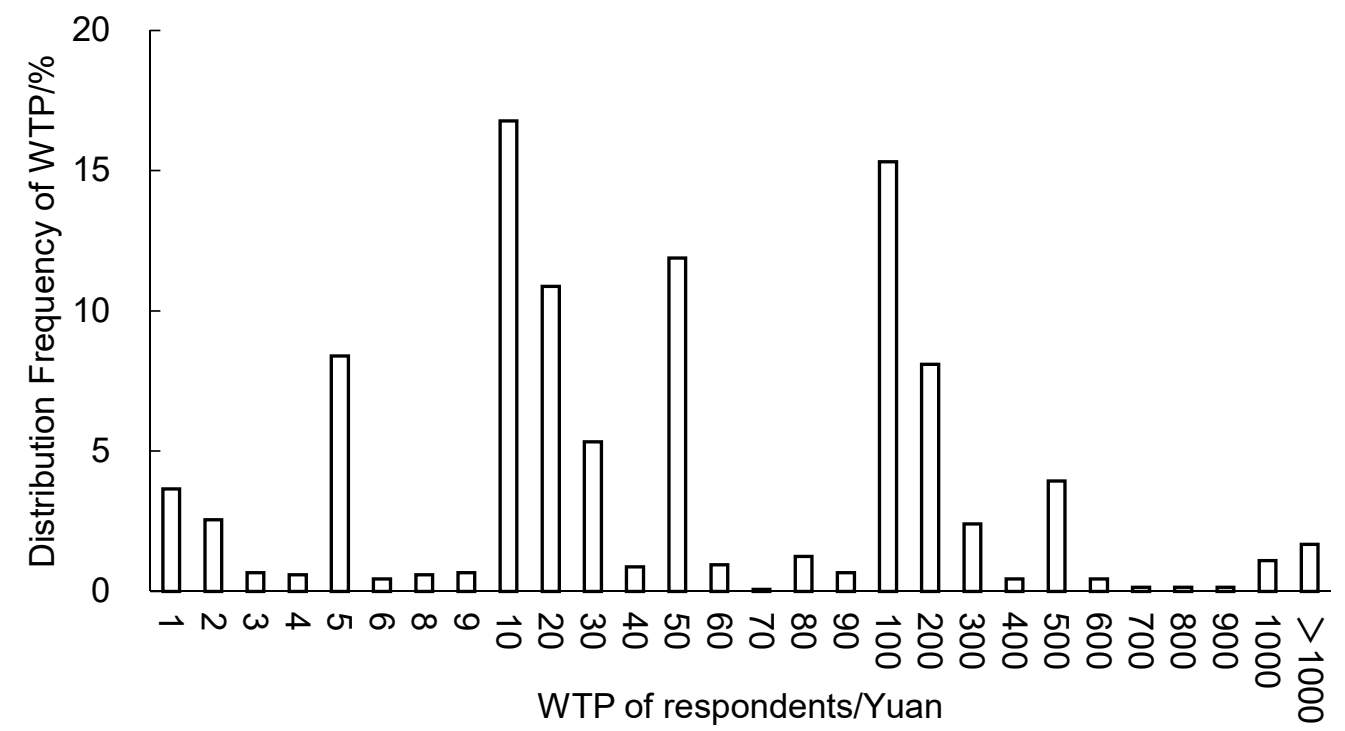

Figure 3.1: Frequency Map of Respondents' WTP in Central Districts

In this survey, 1371 respondents were willing to pay, accounting for $63.2 \%$. Respondents' WTP concentrated distributed in 10 200 yuan. Highest frequency was 10 Yuan, accounting for $16.8 \%$, followed by 100 yuan and 50 yuan, $15.3 \%$ and $11.9 \%$.

797 respondents showed unwillingness to pay, accounting for 36.8\%.There were many reasons for their unwillingness: they think the services should be financed by the government $(38.2 \%)>$ they were unable to pay because of limited income $(17.4 \%)>$ the distance between their homes and the services location was far, hence inconvenient to them $(17.2 \%)>$ they were worried that the money could not really be allocated to the environmentproject $(15.2 \%)>$ others $(7.4 \%)$.

\subsection{Spearman Correlation Analysis of WTP}

Spearman correlation analysis was conducted on the variables affecting the willingness to pay and payment amount, as shown in Table 3.2. Their monthly average income and willingness to participate in certain recreation positively affected their willingness to pay, while their knowledge and satisfaction degree about the green ecosystem in central districts were negatively correlated with their willingness to pay.Respondents' age and average monthly income were positively correlated with payment amount, while education level and satisfaction with green ecosystem in central districts had negative impacts on payment amount.

Table3.2: Spearman Analysis of Respondents' WTP and Influencing Factors

\begin{tabular}{|l|c|c|c|c|}
\hline \multirow{2}{*}{\multicolumn{2}{c|}{ Variable }} & \multicolumn{2}{c|}{ Willingness to pay } & \multicolumn{2}{c|}{ Payment amount } \\
\cline { 2 - 5 } & $\begin{array}{c}\text { Correlation } \\
\text { Coefficient }\end{array}$ & Saliency & $\begin{array}{c}\text { Correlation } \\
\text { Coefficient }\end{array}$ & Saliency \\
\hline Gender & 0.029 & 0.172 & 0.001 & 0.970 \\
\hline Age & 0.014 & 0.522 & $0.104^{* * *}$ & 0.000 \\
\hline Educational level & -0.019 & 0.386 & $-0.100^{* * *}$ & 0.000 \\
\hline Permanent residence (Distance) & 0.003 & 0.902 & 0.013 & 0.618 \\
\hline Average monthly income & $0.081 * * *$ & 0.000 & $0.176^{* * *}$ & 0.000 \\
\hline $\begin{array}{l}\text { Understanding degree of Green Ecosystem in } \\
\text { Central Urban Areas }\end{array}$ & $-0.107 * * *$ & 0.000 & -0.005 & 0.853 \\
\hline
\end{tabular}




\begin{tabular}{|l|c|c|c|c|}
\hline $\begin{array}{l}\text { Satisfaction degree of green ecosystem in } \\
\text { central urban area }\end{array}$ & $-0.166^{* * *}$ & 0.000 & $-0.121^{* * *}$ & 0.000 \\
\hline Willingness to re-visit & $0.219^{* * *}$ & 0.000 & 0.021 & 0.430 \\
\hline Sample size & \multicolumn{2}{|c|}{2168} & \multicolumn{2}{|c|}{1371} \\
\hline
\end{tabular}

Data resource: Processed from survey; "*", "**" and "***" represent the significance levels of $0.1,0.05$ and 0.01 respectively

\subsection{Regression Analysis of WTP}

According to the descriptive statistical analysis of the willingness to pay, we assigned values to all the variables in the survey. The assigned values of the variables and their explanations are shown in table 3.3.Binary Logistic and Ordinal regression analysis were applied to analyse the variables affecting the willingness and quantity of payment of the surveyed residents, and the results were shown in table 3.4. The Hosmer-Lemeshow goodness of fit test for binary logistic regression analysis obtained the $\mathrm{P}$-value of 0.644 . It meant that this regression model was able to accept the survey data showing high reliability with prediction accuracy reaching $67.7 \%$. In the Ordinal regression analysis, the P-value of the parallel line test was 0.106 , indicating that the parameter estimation was accurate and reliable.

As can be seen from the table:

(1) The monthly average income of the residents interviewed has a significant positive impact on the willingness to pay and the amount of payment, and both of them have passed the significance level test of $1 \%$. This shows that with the increase of income level, residents have higher willingness to pay and higher payment amount.

(2) The respondents' age, satisfaction degree and understanding degree have a significant negative impact on the willingness to pay, which has passed the significance level test of $1 \%, 5 \%$ and $1 \%$, respectively. The more the residents are satisfied with the leisure and entertainment services of the urban green ecosystem in the central urban area, the more they know about the services, and the older the residents are, the less willing they are to pay.

(3) Whether the respondents will go to the urban green ecosystem in the central city again for leisure and entertainment has a significant positive impact on their willingness to pay, passing the $1 \%$ significant level test.It indicates that the stronger the willingness of the residents to accept the urban green ecosystem leisure and entertainment services in the central urban area again, the higher their willingness to pay is.

(4) The education level of respondents has a significant negative impact on the amount of payment they transact,and has a negative but not significant impact on the willingness to pay.

Table 3.3: Explanation and Description of Model Variables

\begin{tabular}{|l|l|c|c|}
\hline \multicolumn{1}{|c|}{ Variable } & \multicolumn{1}{|c|}{$\begin{array}{c}\text { Variable Description and Assignment } \\
\text { Method }\end{array}$} & $\begin{array}{c}\text { Standard } \\
\text { Average } \\
\text { Deviation }\end{array}$ \\
\hline Gender & 1=Male; 0=Female & 0.50 & 0.01 \\
\hline Age & $\begin{array}{l}1=20 \text { years old and below; 2=21-30 years } \\
\text { old; 3=31-40 years old; 4=41-50 years } \\
\text { old; 5=51-60 years old; 6=60 years old } \\
\text { and above }\end{array}$ & 2.29 & 0.03 \\
\hline Educational level & $\begin{array}{l}\text { 1= Primary and below; 2= Junior Middle } \\
\text { school; 3= Senior Middle school or } \\
\text { Technical secondary; 4= college; } \\
\text { 5=Postgraduate and above }\end{array}$ & 3.89 & 0.02 \\
\hline
\end{tabular}




\begin{tabular}{|c|c|c|c|}
\hline Average monthly income & $\begin{array}{l}1=2000 \text { yuan and below; } 2=2001-4000 \\
\text { yuan; } 3=4001-6000 \text { yuan; } 4=6001-8000 \\
\text { yuan; } 5=8001-10000 \text { yuan; } 6=10000 \text { yuan } \\
\text { and above }\end{array}$ & 2.33 & 0.03 \\
\hline Permanent residence (Distance) & $\begin{array}{l}\text { 1=Central Districts; } 0=\text { Non-Central } \\
\text { Districts }\end{array}$ & 0.58 & 0.01 \\
\hline $\begin{array}{l}\text { Understandingdegree of Green } \\
\text { Ecosystem in Central Urban Areas }\end{array}$ & $\begin{array}{l}1=\text { Very well; } 2=\text { Roughly; } 3=\text { So-so; } 4=\text { Not } \\
\text { exactly; 5=Completely unclear }\end{array}$ & 2.87 & 0.02 \\
\hline $\begin{array}{l}\text { Satisfaction degree of green } \\
\text { ecosystem in central urban area }\end{array}$ & $\begin{array}{l}\text { 1=Highly Satisfied; } 2=\text { Satisfied; } 3=\text { So-so; } \\
\text { 4=Dissatisfied; } 5=\text { Totally Dissatisfied }\end{array}$ & 2.57 & 0.02 \\
\hline Willingness to re-visit & $1=$ Yes; $0=$ No & 0.95 & 0.00 \\
\hline Whether would like to pay & $1=$ Yes; $0=$ No & 0.63 & 0.01 \\
\hline Payment amount & $\begin{array}{l}1=100 \text { yuan and below; } 2=100 \text { to } 500 \\
\text { yuan; } 3=500 \text { yuan and above }\end{array}$ & 1.17 & 0.01 \\
\hline
\end{tabular}

Data resource: Processed from survey

Table 3.4: Average WTP of Residents and Its Influencing Factors

\begin{tabular}{|c|c|c|c|c|}
\hline \multirow[b]{2}{*}{ Variable } & \multicolumn{2}{|c|}{ Binary Logistic Regression } & \multicolumn{2}{|c|}{ Ordinal Regression } \\
\hline & Coefficient & $\begin{array}{l}\text { Standard } \\
\text { error }\end{array}$ & Coefficient & $\begin{array}{c}\text { Standard } \\
\text { error }\end{array}$ \\
\hline Gender & -0.054 & 0.095 & -0.168 & 0.146 \\
\hline Age & $-0.192 * * *$ & 0.046 & -0.024 & 0.068 \\
\hline Educational level & -0.082 & 0.066 & $-0.319 * * *$ & 0.091 \\
\hline Permanent residence（Distance） & -0.036 & 0.096 & 0.049 & 0.146 \\
\hline Average monthly income & $0.191^{* * *}$ & 0.038 & $0.320 * * *$ & 0.050 \\
\hline $\begin{array}{l}\text { Understandingdegree of Green Ecosystem in } \\
\text { Central Urban Areas }\end{array}$ & $-0.158 * *$ & 0.061 & $0.168 *$ & 0.091 \\
\hline $\begin{array}{l}\text { Satisfaction degree of green ecosystem in } \\
\text { central urban area }\end{array}$ & $-0.428 * * *$ & 0.068 & $-0.503 * * *$ & 0.113 \\
\hline Willingness to recreation again & $2.120 * * *$ & 0.270 & 0.441 & 0.761 \\
\hline Constant & 0.466 & 0.445 & - & - \\
\hline threshold 1 & - & - & 0.676 & 0.935 \\
\hline threshold 2 & - & - & $1.738 *$ & 0.937 \\
\hline Sample size & \multicolumn{2}{|c|}{2168} & \multicolumn{2}{|c|}{1371} \\
\hline
\end{tabular}

Data resource: Processed from survey; "*", "**" and "***" represent the significance levels of $0.1,0.05$ and 0.01 respectively

\subsection{Sensitivity Analysis of WTP}

The sensitivity of willingness to pay wasanalysed by applying logistic regression model.The selected variables were four significant factors with willingness to pay: age $\left(X_{1}\right)$, average monthly income $\left(X_{2}\right)$, satisfaction degree of green ecosystem in central urban area $\left(X_{3}\right)$, and willingness to take part in recreation again $\left(X_{4}\right)$. The regression equation of Total sample could be obtained: 


$$
\operatorname{In}\left(\frac{P}{P-1}\right)=0.466-0.192 X_{1}+0.191 X_{2}-0.428 X_{3}+2.120 X_{4}
$$

Then the probability $\mathrm{P}$ of the total sample is:

$$
P=\frac{\exp \left(0.466-0.192 X_{1}+0.191 X_{2}-0.428 X_{3}+2.120 X_{4}\right)}{1+\exp \left(0.466-0.192 X_{1}+0.191 X_{2}-0.428 X_{3}+2.120 X_{4}\right)}
$$

Respondents' age, monthly average income, satisfaction degree of green ecosystem in central urban area, and willingness to take part in recreational activities were all significantly above the $1 \%$ level, indicating that these four factors could better predict the respondents' willingness to pay. Among them, the coefficient of recreation reached 2.120 again, which was greater than the absolute value of the other three coefficients, that is, the willingness to pay was the most sensitive to the willingness to participate in recreation again.

\subsection{Sensitivity Analysis of Payment Amount}

The sensitivity of payment amount wasanalysed by using ordinal regression model. The selected variables were of three factors that are significant in terms of the amount of payment: educational level $\left(X_{I}\right)$, average monthly income $\left(X_{2}\right)$, and satisfaction with the urban green ecosystem in central cities $\left(X_{3}\right)$. ( $Y=1,2,3 ; 1=$ payment of 100 yuan and below, $2=$ payment of 100 to 500 yuan, $3=$ payment of 500 yuan and above )

Two regression equations can be obtained:

$$
\begin{aligned}
& \operatorname{In}\left(\frac{P(Y \leq 1)}{1-P(Y \leq 1)}\right)=0.676-\left(-0.319 X_{1}+0.320 X_{2}-0.503 X_{3}\right) \\
& \operatorname{In}\left(\frac{P(Y \leq 2)}{1-P(Y \leq 2)}\right)=1.738-\left(-0.319 X_{1}+0.320 X_{2}-0.503 X_{3}\right)
\end{aligned}
$$

The probability $\mathrm{P}$ of the total sample is:

$$
\begin{aligned}
& P(Y \leq 1)=\frac{\exp \left[0.676-\left(-0.319 X_{1}+0.320 X_{2}-0.503 X_{3}\right)\right]}{1-\exp \left[0.676-\left(-0.319 X_{1}+0.320 X_{2}-0.503 X_{3}\right)\right]} \\
& P(Y \leq 2)=\frac{\exp \left[1.738-\left(-0.319 X_{1}+0.320 X_{2}-0.503 X_{3}\right)\right]}{1-\exp \left[1.738-\left(-0.319 X_{1}+0.320 X_{2}-0.503 X_{3}\right)\right]}
\end{aligned}
$$

The respondents' education level, monthly average income and satisfaction degree of green ecosystem in central urban areawere all significantly above the $1 \%$ level, indicating that these three factors could better predict the payment amount of the respondents. Among them, the coefficient of satisfaction degree was -0.503 , whose absolute value is the largest, that is, the payment amount is the most sensitive to the satisfaction degree.

\subsection{Value Assessment of Green Ecosystem Leisure Services in Central Urban Areas}

Based on the analysis of residents' willingness to pay and the influencing factors, the value of leisure and entertainment services of the urban green ecosystem was further evaluated economically. And further evaluationof the value of leisure and entertainment services of green ecosystem in each district is shown in Table 3.5. The value of leisure and entertainment services of green ecosystem in central urban area was counted as $7.463 \sim 11.019$ billion yuan. 
Table 3.5: Value Distribution of Leisure Services in Each District's Green Ecosystem

\begin{tabular}{|c|c|c|c|c|c|}
\hline District & $\begin{array}{c}\text { positive } \\
\text { payment } \\
\text { rate/\% }\end{array}$ & $\begin{array}{c}\text { E(WTP)lower } \\
\text { limit /yuan }\end{array}$ & $\begin{array}{c}\text { E(WTP)Upper } \\
\text { limit /yuan }\end{array}$ & $\begin{array}{c}\text { Q lower limit } \\
\text { /billion yuan }\end{array}$ & $\begin{array}{c}\text { Q Upper limit } \\
\text { /billion yuan }\end{array}$ \\
\hline Wuchang & 57.4 & 22.8 & 39.8 & 0.249 & 0.434 \\
\hline Qiaokou & 60.3 & 80.3 & 133.2 & 0.875 & 1.450 \\
\hline Qingshan & 62.6 & 88.9 & 142.1 & 0.969 & 1.547 \\
\hline Jiang'an & 64.9 & 126.3 & 194.5 & 1.375 & 2.119 \\
\hline Hongshan & 69.2 & 104.5 & 151.1 & 1.139 & 1.645 \\
\hline Jianghan & 73.5 & 165.0 & 224.5 & 1.798 & 2.446 \\
\hline Hanyang & 76.9 & 97.2 & 126.5 & 1.059 & 1.377 \\
\hline Central & 63.2 & - & - & 7.463 & 11.019 \\
\hline
\end{tabular}

Data resource: Processed from survey

\section{DISCUSSIONS}

(1) The probability of residents' WTP in the Central Districts was $63.24 \%$, the positive payment rate of each district was: Hanyang District (76.9\%) > Jianghan District (73.5\%) > Hongshan District (68.2\%) > Jiang'an District (64.9\%) > Qingshan District $(62.6 \%)>$ Qiaokou District $(60.3 \%)>$ Wuchang District $(57.4 \%)$. The value of the entertainment service of the urban green ecosystem in the Central Districts was $7.463 \sim 11.019$ billion yuan, among which the results of each districts were as follows: Jianghan District (2.122 billion yuan) > Jiang'an District (1.747 billion yuan) $>$ Hongshan District $(1.392$ billion yuan) $>$ Qingshan District (1.258 billion yuan) $>$ Hanyang District (1.218 billion yuan) $>$ Qiaokou District $(1.163$ billion yuan) $>$ Wuchang District (0.341 million yuan). We can speculate that the residents' WTP for urban green ecosystem and the amount of payment were quite imparity in different regions.

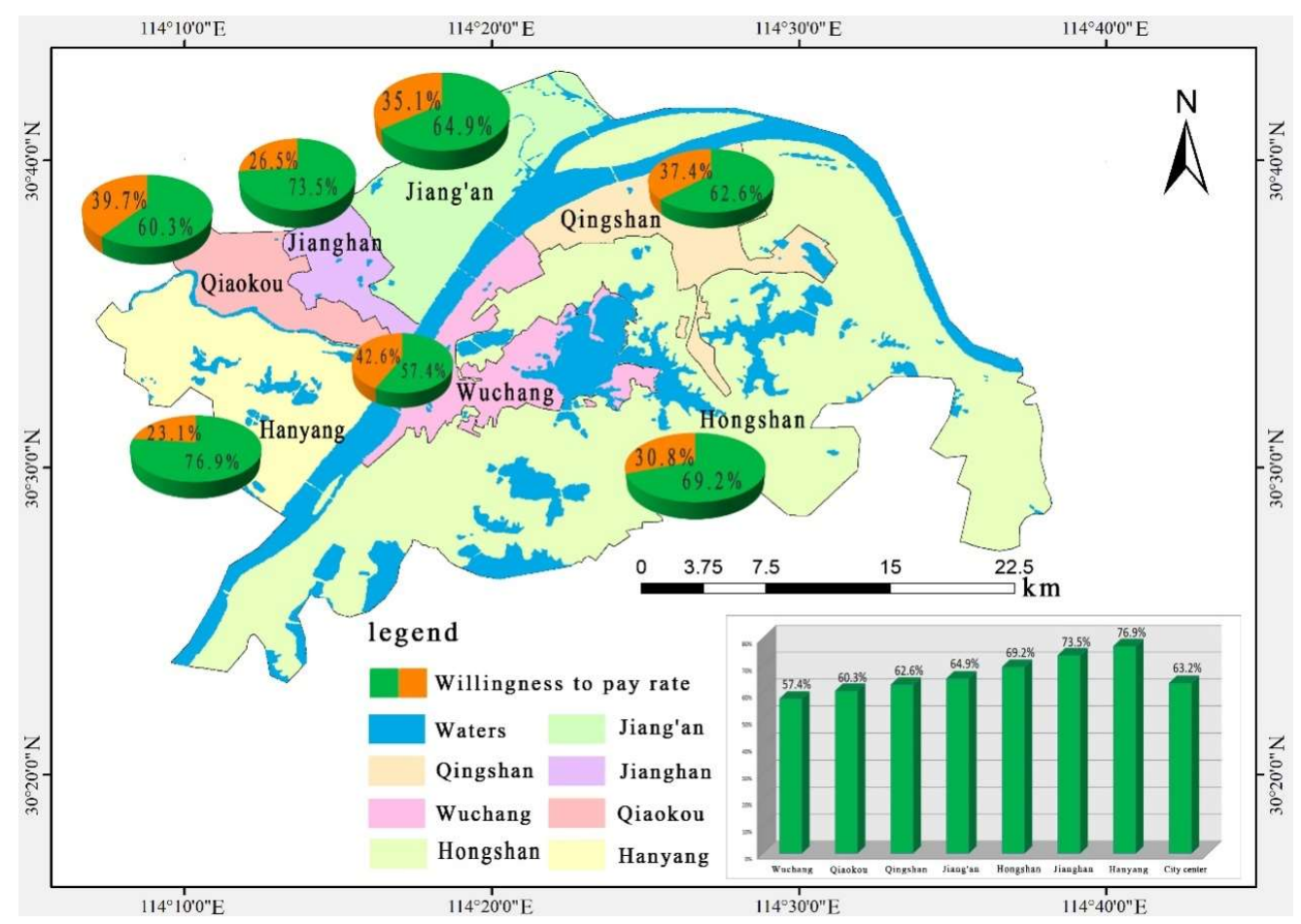

Figure 4.1: Distribution of Willingness to Pay Rate in Central Districts 


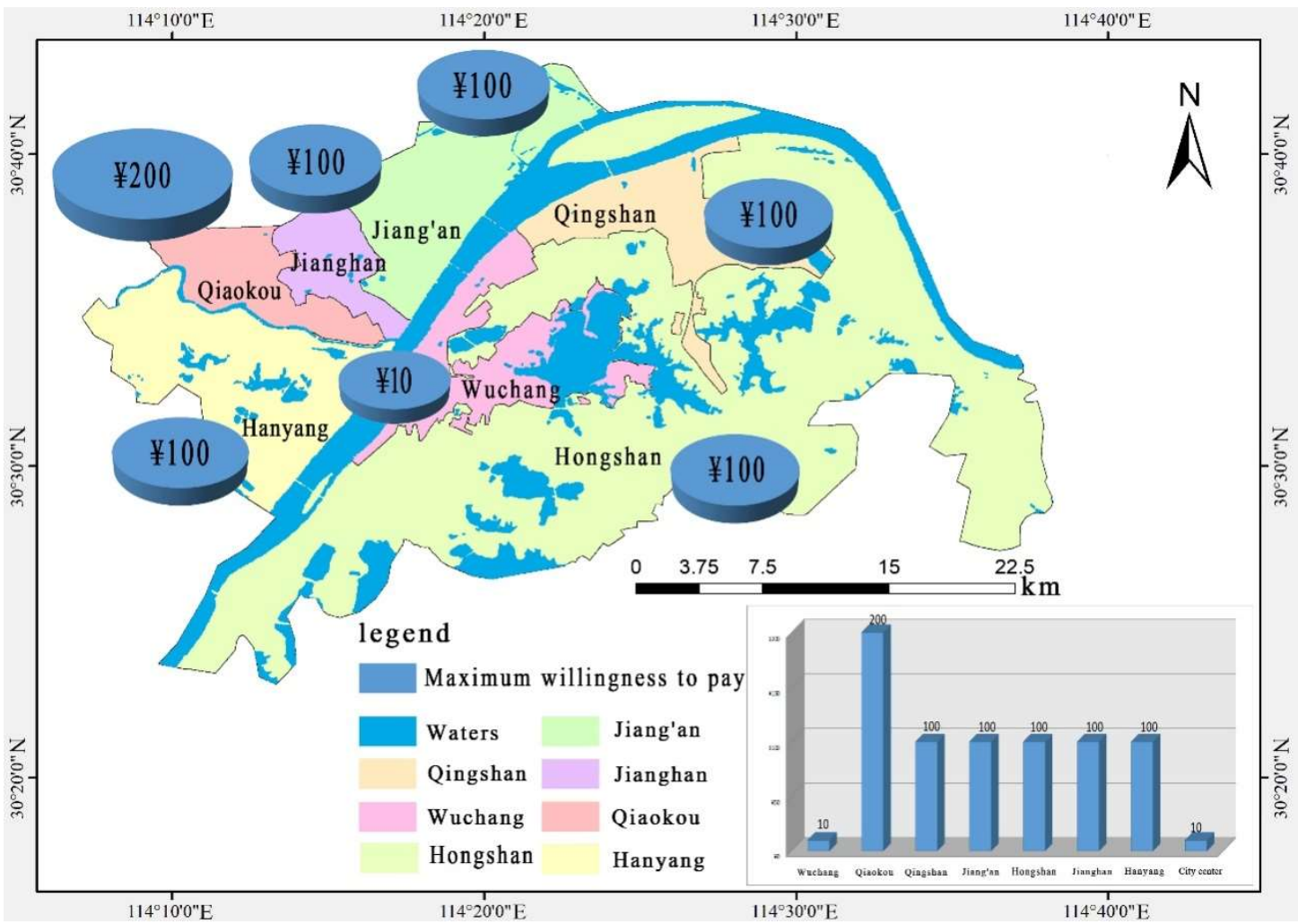

Figure 4.2: Distribution of Maximum Willingness to Pay of Central districts

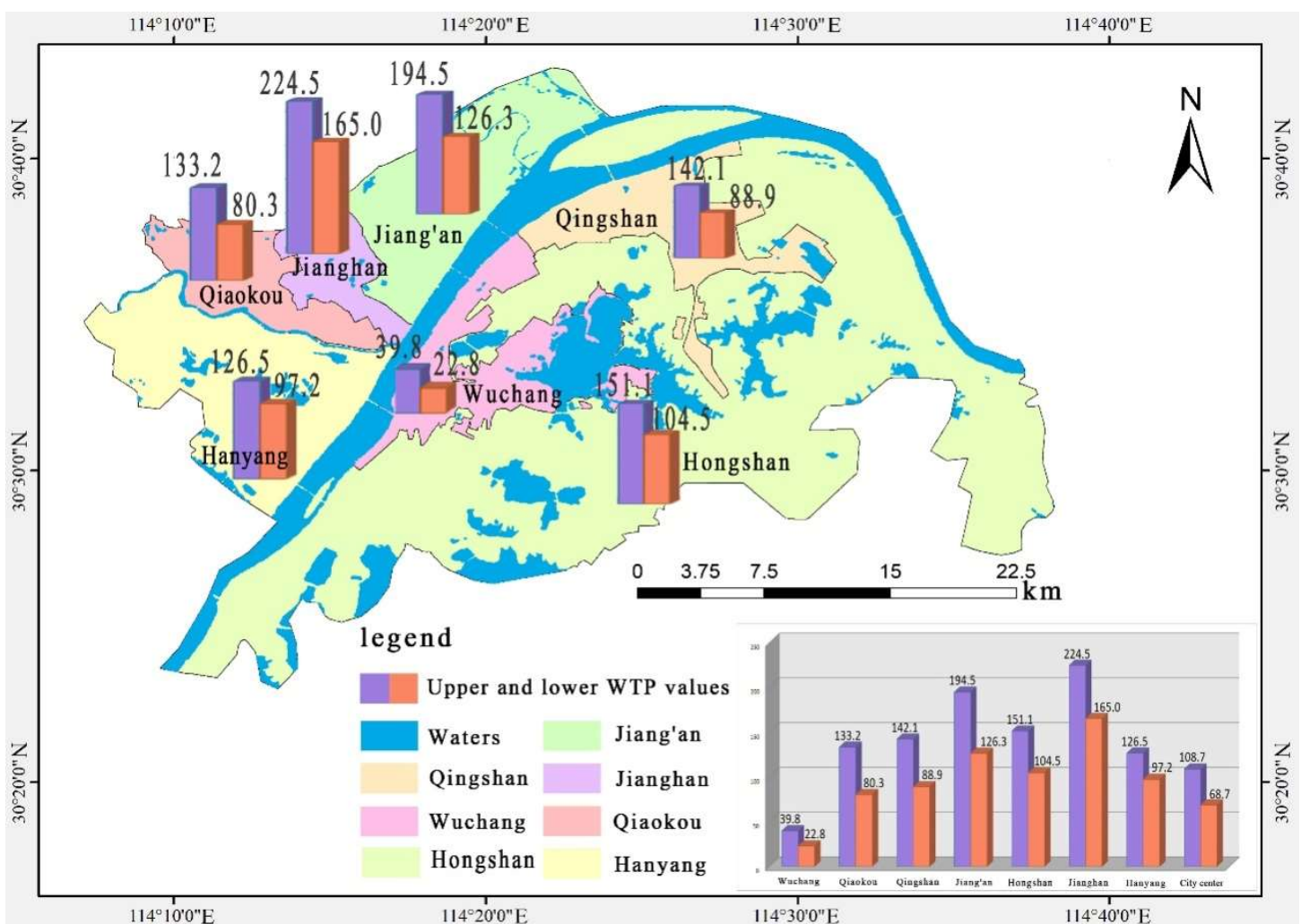

Figure 4.3: Distribution of Residents' WTP Upper and Lower Limits 


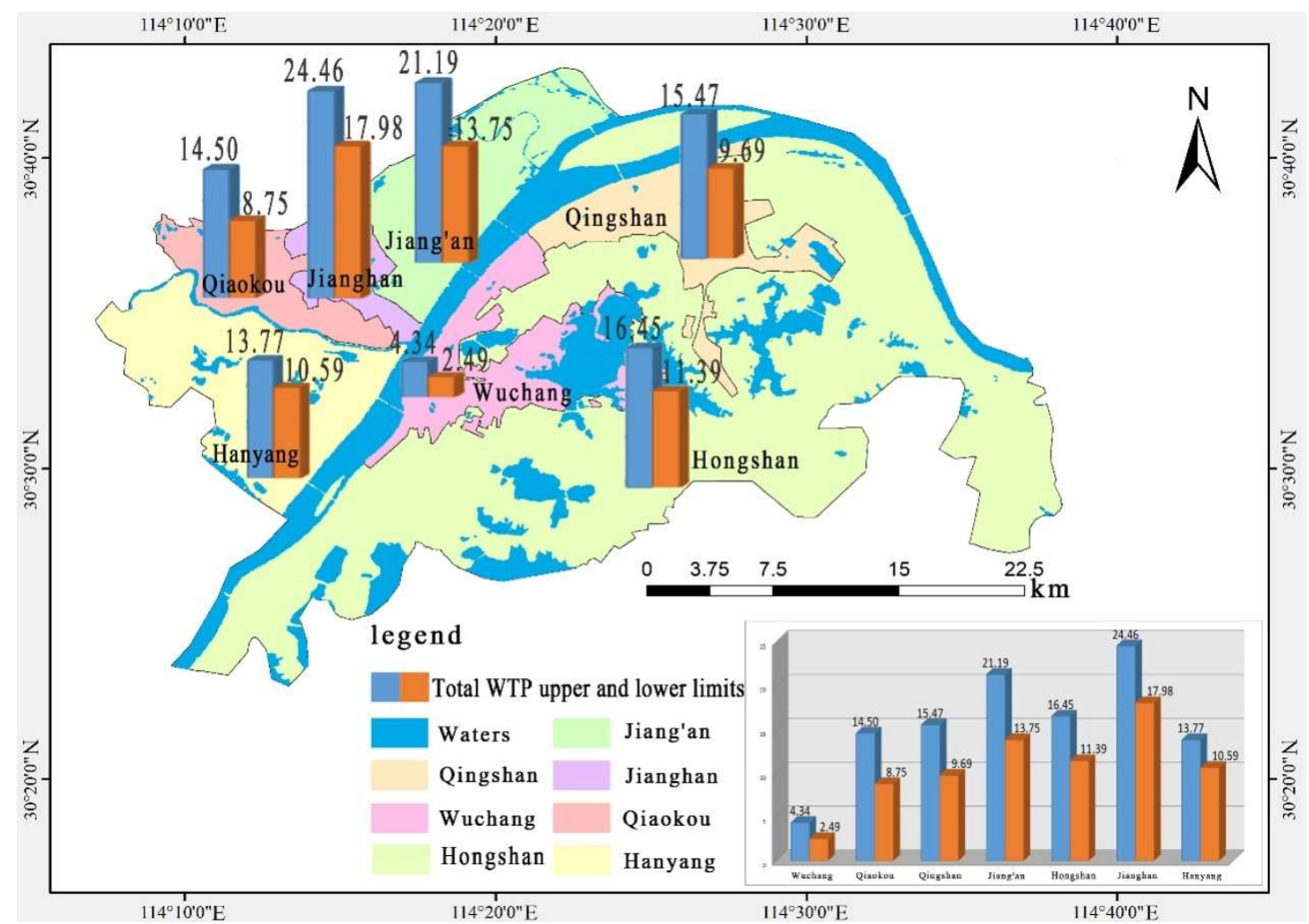

Figure 4.4: Distribution of Upper and Lower Limits of Green Ecological System of Leisure Services Value

Spearman correlation analysis and binary logistic and ordered ordinal regression analysis were conducted out on the probability and the amount of residents' WTP, it can be seen that the factors affecting the $1 \%$ significant level were basically the same.In general, with the improvement of economic level, people will have a higher WTP, and the results of this survey were consistent with this. In addition, non-economic factors such as gender, age, and satisfaction also have a great impact on people's WTP. As far as the Central Districts of Wuhan City was concerned, the residents' age had a significant negative impact on their WTP; residents' educational level and satisfaction with urban green ecosystem had significant negative effects on the probability and amount of the residents' WTP; residents' understanding of urban green ecosystem had a significant negative impact on their WTP while a significant positive impact on the amount of payment; and the willingness to participate in recreation had a significant positive impact on the WTP.

Generally, the higher the level of education people got, the clearer understanding about recreation of urban green ecological system service functions they would possess, consciousness with the green environmental protection would be greater, as well as the willingness to pay and payment amount would be higher. Meanwhile, results of regression analysis were at polar opposite. It reflected the deviation between people's cognition of payment intention and payment behaviour of urban green ecosystem leisure services, and some had fluke mind of "hitch-hike". In addition, there were 851 students with high level of education among the respondents whose income level was low, affecting the data results of the research. People's willingness to re-visit had a significant positive impact on their willingness to pay. The age of respondents has a significant negative impact on their willingness to pay. This may be because the targets of this study are mainly middle-aged and young people, who might get stressed out due to the increase in consumption and survival pressure with the increase of age at this stage. We found out by analysing the willingness to pay and the sensitivity of the amount paid that willingness to pay is the most sensitive to the willingness to re-visit, while payment amount is the most sensitive to satisfaction. 
(2) Among the main reasons of respondents' unwillingness to pay in every district was the fact that the statement "It should be financed by the government" always occupied the highest proportion, accounted for at least $30.0 \%$. This indicated that the respondents of urban green ecosystem protection were still unclear. Certainly, the construction and development of urban ecosystem were the responsibility of the government. But citizens were the beneficiaries of the city's green ecosystem. Direct or indirect public participation could make positive effects. The government could publicize and guide correctly to improve the whole society residents' awareness of the service value of urban green ecosystem and awaken their awareness of the environmental responsibility. The second reason for respondents' unwillingness to pay was being "Unable to pay because of limited income". With the rapid development of China's economy, people's income level has been constantly improved. With times, these residents would also have a growing willingness to pay. Distance and inconvenient traffic were also marked as important reasons why residents were reluctant to pay. In the future, transportation factors should be taken into consideration in the development and construction of urban green ecosystem. It is also possible to create feature pocket parks in or near the neighbourhood, to benefit urban residents.

(3) With the rapid development of China's economy and the continuous improvement of people's income level, people's yearning for a better life becomes increasingly strong, and their cognitive deviation of leisure and entertainment service in urban green ecosystem continue to shrink. Laws and regulations of the relevant government departments are increasingly soundly implemented. The value of leisure and entertainment services in the urban green ecosystem will continue to rise, with great potential for further development.

There were some differences between our survey and previous studies ${ }^{[15-20]}$. Reasons lay in that CVM estimation results were restricted by such factors as the difference in economic attributes between the research object and the interviewee. However, judging the range of WTP mean value, positive payment rate and total WTP value, the results of our survey were in the normal range. Likewise, it can be seen that the value of urban green ecosystem leisure and entertainment services in different cities are positively correlated with the urban economic level.

This survey applied the CVM method to establish a hypothetical market to evaluate the leisure services of urban green ecosystem.But respondents' willingness to pay was affected by uncertain factors such as economic level and social environment. The calculated value might deviate from the actual value, but this did not affect our understanding of the value of the urban green ecosystem leisure services. At the same time, people's income level, degree of education level, satisfaction, and willingness tore-visit affected their willingness to pay. Therefore, the assessment results are timely. Long-term investigation and further research are needed to analyse the trend of leisure value of the urban green ecosystem in the future.

\section{CONCLUSIONS}

(1) The probability of residents' positive WTP in the Central Districts was $63.2 \%$, the positive payment rate of each district, from high to low, were as follows: Hanyang District $(76.9 \%)>$ Jianghan District $(73.5 \%)>$ Hongshan District $(68.2 \%)>$ Jiang'an District (64.9\%) > Qingshan District (62.6\%) > Qiaokou District (60.3\%) > Wuchang District (57.4\%). The value of the entertainment service of the urban green ecosystem in the Central Districts was $7.463 \sim 11.019$ billion yuan, among which the results of each districts were as follows: Jianghan District (2.122 billion yuan) > Jiang'an District $(1.747$ billion yuan $)>$ Hongshan District $(1.392$ billion yuan $)>$ Qingshan District (1.258 billion yuan) $>$ Hanyang District (1.218 billion yuan) >Qiaokou District (1.163 billion yuan) $>$ Wuchang District (0.341 million yuan).

(2) Most of the residents still had a vague definition of the subject of urban green ecosystem protection and believed that urban green ecosystem should be constructed and developed by the government. The government could publicize and give correct guidance to raise the whole society residents' awareness of the service value of the urban green ecosystem and awaken their interestsin environmental responsibility. It is also possible to create feature pocket parks in or near 
neighbourhoods, to let the urban benefit urban residents benefit from the program in years to come.

(3) Residents' willingness to pay for leisure and entertainment services in the urban green ecosystem is not only a reflection of income level, but also related to gender, age, satisfaction degree and other non-economic factors. The degree of education of the residents and their satisfaction levels with the urban green ecosystem had a significant negative impact on the willingness to pay and the amount of payment. Their understanding of urban green ecosystem had a significant negative impact on their willingness to pay and a significantly positive impact on the amount of payment. The education levels of the residents had a significantly negative impact on the amount of payment. Residents' willingness tore-visit the service locationshad a significant positive impact on their willingness to pay. The willingness to pay was the most sensitive to their intention to participate in recreation and the amount of payment was the most sensitive to their satisfaction.

Author Contributions: L. Z., C. W., M.X., B.C. were responsible for the overall design of the study and contributed to theproofreading of the manuscript. C. W., Z.G., Q.Z., Y.Z. performed the experiments, analysed and interpreted the data, wrote themanuscript, and helped with the proofreading of the manuscript.L. Z. and C. W.contributed to designing thestudy and the proofreading of the manuscript. All authorsread and approved the final manuscript.

Funding: This research was funded by College Students' Innovative Entrepreneurial Training Plan Program (S201910512085, 201810512109).

ACKNOWLEDGMENTS: We gratefully acknowledge the help of College Students' Innovative Base of Environmental Science and Engineering in Hubei province.

Conflicts of Interest: The authors declare no conflicts of interest.

\section{REFERENCES}

1. Lederbogen F, Kirsch P, Haddad L, et al. City living and urban upbringing affect neural social stress processing in humans[J], Nature, 2011, 474(7352): 498-501.

2. Gómez-Baggethun E, Barton D N. Classifying and valuing ecosystem services for urban planning [J]. Ecological Economics, 2013, 86(1): 235-245.

3. Bolund P, Hunhammar S. Ecosystem services in urban areas [J]. Ecological Economics, 1999, 29(2): $293-301$.

4. Kronenberg J. Urban ecosystem services [J]. Sustainable Development Applications, 2012, (3): 13-30.

5. Li F, Wang R S, Zhao D. Urban ecological infrastructure based on ecosystem services: status, problems and perspectives [J]. Acta Ecologica Sinica, 2014, 34(1):190-200.

6. SAXENA, AR MANITA, and SUPRIYA VYAS. "PERI-URBAN AREAS: SUSTAINABILITY DIMENSION." International Journal of Mechanical and Production Engineering Research and Development (IJMPERD)9.2, Apr 2019, 545-554

7. Mao $Q$ Z, Huang G L, Wu J G. Urban ecosystem services: A review [J]. Chinese Journal of Applied Ecology, $2015,26(4): 1023-1033$

8. Davis R K. Recreation planning as an economic problem [J]. Natural Resources Journal, 1963, (3): 239-249.

9. Shaoqing, Tang, Lu Ran, and Pengfei Jiang. "The Analysis of Nostalgia Element Among the New Develop Rural-Urban Integration in Beijing." International Journal of Economics Commerce and Research (IJECR) 6.3 (2016).

10. Zhang $Z Q, X u Z M$, Cheng $G D$. The updated development and application of contingent valuation method [J]. Advances in Earth Science, 2003(03):454-463.

11. Spash C L. Non-Economic Motivation for Contingent Values: Rights and Attitudinal Beliefs in the Willingness to Pay for Environmental Improvements [J]. Land Economics, 2006, 82(4): 602-622.

12. Santos A C, Roberts J A, Barreto M L, et al. Demand for sanitation in Salvador, Brazil: A hybrid choice approach [J]. Social Science \& Medicine, 2011, 72(8):1325-1332.

13. Basili M, Matteo M D, Ferrini S. Analysing demand for environmental quality: A willingness to pay/accept study in the province of Siena (Italy) [J]. Waste Management, 2006, 26(3):209-219.

14. ATHIRA, RAVI, and V. SUBHA. "SUSTAINABLE SOLID WASTE MANAGEMENT SOLUTIONS TO KOCHI CITY, INDIA, THROUGH THE ENVIRONMENTAL MANAGEMENT TOOL ECOLOGICAL FOOTPRINT ANALYSIS." Research and 
Development (IJCSEIERD) 3.1 (2013): 67-78.

15. Ao C L, Chen J T, Jiao Y, et al. The effect of distance on the ecological conservation value: a case study of Sanjiang Plain Wetland [J]. Acta Ecologica Sinica, 2013, 33(16):5109-5117.

16. Patel, RAVI K., and JATIN V. Raval. "Avian Diversity at Prashnavada Wetland, Girsomnath District, Gujarat, India." International Journal of Environment, Ecology, Family and Urban Studies 9 (2019): 95-104.

17. Hammitt J K. Implications of the WTP-WTA Disparity for Benefit-Cost Analysis [J]. Journal of Benefit-Cost Analysis, 2015, 6(1): 207-216.

18. He K, Zhang J B, Feng J H. Non-market value of prevention and control of agricultural waste pollution based on contingent valuation method[J]. Resources and Environment in the Yangtze Basin, 2014, 23(2):213-219.

19. Zhang L Y, Jiang B, Zhen Q, et al. Evaluation of Non-use Value of Dongting Lake Ecosystem[J]. Wetland Science, 2016 , 14(06):854-859.

20. Xue D Y. Valuation on non-use values of biodiversity by contingent valuation method in Changbai Mountain Biosphere Reserve in China [J]. China Environmental Science, 2000, 20(2):141-145.

21. TRIVEDI, PRACHI, and MEGHNA SHARMA. "Impact Of Green Production And Green Technology On Sustainability: Cases On Companies In India." International Journal of Mechanical and Production Engineering Research and Development (IJMPERD) (2017).

22. Shi J L, Li Z Y, Cheng G, et al.Evaluation of Non-use Value of Tourism Resources Based on CVM: A Case Study of Xiangshawan in Inner Mogolian[J]. China Population, Resources and Environment 2014, 24(S2):360-364.

23. Zhu J J, Huang X J, Ding Z M. Recreation Value Evaluation of Fuzhou National Forest Park Based on CVM [J].Issues of Forestry Economics, 2016, 36(05):445-449.

24. Ouyang J G, Ou XW. Ou Yang J G, et al. Evaluation of Non-use Value of Ecosystem in Guangdong Eco-development zone [J]. Journal of Zhuhai Administrative College, Party School of Zhuhai Municipal Committee of the CPC, 2016(06):38-51+60.

25. Jiang S Y, Cao M, Tang C D, et al. Non-use value assessment of Chongming wetland based on contingent valuation method[JJ. Journal of Nanjing Forestry University (Natural Sciences Edition), 2017, 41(01):21-27. 



\section{www.tiprc.org}

